\title{
Büyüklenmeci Narsisizmin İki Farklı Yüzü: Narsistik Hayranlık ve Rekabetin Mutlulukla İlişkisi
}

\author{
Two Different Faces of Grandiose Narcissism: Relationship among Narcissistic \\ Admiration and Rivalry, and Happiness
}

\author{
İbrahim DEMİRCI'* \\ Füsun EKŞi๋**
}

\begin{abstract}
$\ddot{\mathbf{O z}}$
$\mathrm{Bu}$ çalışmanın amacı narsistik hayranlık ve rekabetin mutlulukla ilişkisini incelemektedir. Narsisizmi anlamaya yönelik bugüne kadar çeşitlik modeller geliştirilmiştir. Bu modellerden biri olan narsistik hayranlık ve rekabet modeli büyüklenmeci narsisizmin iki farklı yönünü ortaya koymaktadır. Araştırmada öncelikle Narsistik Hayranlık ve Rekabet Ölçeğinin uzun ve kısa formları Türkçeye uyarlanarak psikometrik özellikleri incelenmiştir. İkinci çalışmada ise narsistik hayranlık ve rekabet ile mutluluk arasındaki ilişkiler yapısal eşitlik modeliyle incelenmiştir. Doğrulayıcı faktör analizi sonucunda Narsistik Hayranlık ve Rekabet Ölçeği’nin kısa ve uzun formları uyum iyiliği indekslerinin kabul edilebilir düzeyde olduğu görülmüştür. Ölçeğin alt boyutlarının iç tutarlık katsayıları 60'ın üzerinde bulunmuştur. Narsistik hayranlık ve rekabet ile Narsistik Kişilik Envanteri arasındaki korelasyon katsayılarının pozitif yönde anlamlı olduğu görülmüştür. İkinci çalışmada Narsistik hayranlığım mutluluğu pozitif yönde yordadığı, narsistik rekabetin ise mutluluğu negatif yönde yordadığı bulunmuştur. Narsisizmin ve mutluluk arasındaki iki yönlü ilişki literatür eşliğinde tartışılmıştır.
\end{abstract}

Anahtar Kelimeler: Narsisizm, mutluluk, hayranlık, rekabet, yapısal eşitlik modeli

\begin{abstract}
The purpose of this study is to examine the relationship of narcissistic admiration and rivalry to happiness. Until now, various models have been developed for the meaning of narcissism. One of these models, narcissistic admiration and rivalry model reveals two different directions of grandiose narcissism. In the study, psychometric properties of long and short forms of narcissistic admiration and rivalry scale were firstly adapted to Turkish. In the second study, narcissistic admiration and relationships between competition and happiness were examined by
\end{abstract}

* Dr., Milli Eğitim Bakanlığı, Sinop, E-Posta: ibrahimdemircipdr@gmail.com

** Yrd. Doç. Dr., Füsun Ekşi, İstanbul Medeniyet Üniversitesi, İstanbul, E-Posta: eksifusun@gmail.com 
structural equality model. As a result of confirmatory factor analysis, the short and long forms of the Narcissistic Admiration and rivalry Scale were found to be acceptable for the goodness of fit indexes. Internal consistency coefficients of subscales of the scale were found above .60 . The correlation coefficients between narcissistic admiration and rivalry and the Inventory of the Narcissistic Personality were found to be significant in the positive direction. In the second study, my narcissistic admiration found happiness in the positive direction, and narcissistic rivalry found happiness in the negative direction. The two-way relationship between narcissism and happiness has been discussed in the light of literature.

Keywords: Narcissism, happiness, admiration, rivalry, happiness, structural equation modelling

\section{Giriş}

Narsisizm psikolojinin birçok alt alanı için oldukça ilgi çeken bir kavram olmuştur. Narsisizm psikanaliz (Freud, 1914/1957), nesne ilişkileri (Kernberg, 2004), kendilik psikolojisi (Kohut, 1977) kuramlarının temel dinamiklerinden biri olarak, klinik psikolojide bir kişilik bozukluğu olarak (DSM 5, APA, 2013), kişilik psikolojisinde belirgin bir kişilik özelliği olarak (Gentile ve diğerleri, 2013), örgütsel psikolojide liderlik özellikleri (Grijalva, Harms, Newman, Gaddis ve Fraley, 2015) ve kurum kültürünün bir özelliği olarak (Rousseau ve Duchon, 2015), siber psikolojide online davranışların belirleyicilerinden biri olarak (Davenport, Bergman, Bergman ve Fearrington, 2014), kişilerarası ilişkilerin bir dinamiği olarak ve romantik ilişkilerde ilişki doyumunu ve sağlıklı ilişkileri etkileyen önemli bir özellik olarak (Wurst ve diğerleri, 2017) çeşitli boyutlarıyla incelenmiş, kapsamlı, karmaşık ve anlamına yakışır şekilde ilgi çekici bir kavram olmuştur.

Narsisizm, Yunan mitolojisindeki Narkisos mitinden türetilmiştir. Mitolojiye göre genç ve yakışıklı Narkisos kendisine hayran olan birçok kişiyi reddetmiştir. Narkisos tarafından küçümsenmiş bir aşığın duasına cevap veren Tanrıça Nemesis, tıpkı kendisinin daha önce birçok kişiye yaşattığı gibi Narkisos’u karşılıksız aşkla cezalandırmıştır. Narkissos suda kendi yansımasını görerek yansımasına aşık olmuş ve ölene kadar kendi yansımasını umutsuzca izlemiştir (Levy, Ellison ve Reynoso, 2011). Başka bir rivayete göre de aşkına ulaşmak isterken suya düşerek boğulmuş ve düştüğü yerde nergis çiçeği açmıştır.

Narkissos miti ilk olarak Ellis (1898) tarafından kişinin kendine olan hayranlığının cinsel duygularını ortadan kaldırmasıyla sonuçlanan gözlemlerini tanımlamak için kullanılmıştır. Ardından Näcke (1899), Ellis’in Narkissos mitini kullandığı eserin Almanca özetini yayınlarken Narsisizm kavramını benliğin cinsel nesne olarak muamele gördüğü otoerotizm kavramını ifade etmek için kullanmıştır. Freud’a (1914/1957) göre narsisizm libidonun kişinin kendi benliği yönelmesiyle ortaya çıkmaktadır. Freud (1914/1957) narsisizmi birincil ve ikincil narsisizm olmak üzere iki şekilde ele almıştır. Birincil narsisizm gelişimin ilk yıllarında çocuğun kendini dış dünyadan ayıramadığı için kendisini sevgi nesnesi olarak görmesini ifade eden normal bir gelişim aşamasıdır. İkincil narsisizm ise ilerleyen gelişim dönemlerinde dış dünyada aranan 
sevgi nesnesinin bulunamamasıyla libidonun yeniden benliğe yönelmesini ifade eden patolojik özellikler içermektedir.

Horney'e (1939) göre narsisizm kendini sevmenin değil kendine yabancılaşmanın bir ifadesidir. Horney (1939) narsistik eğilimleri olan kişinin kendine ve başkalarına yabancılaştığını vurgulamaktadır. Ona göre insan narsistik olduğu ölçüde kendini ve başkalarını sevme yeteneğini kaybeder. Kişi kendini kaybettiği için kendisi hakkındaki illüzyonlara sarılmaktadır. Horney (1939), benlik saygısı ve kendini yüceltmeyi ayrı olarak değerlendirilmesinin gerektiğini çünkü narsisizmin benliğin gerçekçi olmayan bir şekilde şişirilmesiyle ilgili olduğunu vurgulamaktadır. Bu nedenle Horney, patolojik narsisizm ile sağlıklı benlik saygısının ayrı olarak değerlendirerek narsisizm kavramını benliğin gerçekçi olmayan bir şekilde yüceltilmesiyle sınırlandırılmasını önermiştir (Levy ve diğerleri, 2011).

Kernberg (2004) narsisizm kavramının iki paralel ve birbirini tamamlayıcı tanımı olduğu için narsisizm kavramını açıklamanın zor olduğunu ifade etmektedir. Psikoanalitik teoride narsisizm libidinal enerjinin benliğe yatırımı anlamına gelmektedir. Narsisizmin ikinci tanımlaması ise klinik psikolojide anormal benlik saygısı olan kişileri tanımlamak için kullanılan narsistik kişilik bozukluğudur. Kernberg (1967, 1970, 1975, 1992) narsisizmin ebeveynlerin reddinin, ebeveynlerin tutarsız uygulamalarının ve ebeveynlerin kendi ihtiyaçlarını karşılamak için çocukların kullanıldığı aile ortamında geliştiğini ifade etmektedir. Bazen bir ebeveyn çocuklarını ihmal edip ve küçümserken, kendi ihtiyaçlarına uygun durumlarda ise özenli hatta aşırı ilgili olabilmektedir. Narsisizm çocuğun soğuk ve reddedici ebeveyni karşısında savunmaya geçerek kendi benliğini yüceltmesiyle telafi edici bir işlev gösterebilmektedir (Akt., Levy, Ellison ve Reynoso, 2011).

Kernberge (2004) göre normal çocukluk ve yetişkinlik narsisizmi ile patolojik narsisizm birbirinden çeşitli yönleriyle ayrılmaktadır. Patolojik narsisizm ise çocukluk narsisizminin benlik saygısı düzenleme mekanizmalarına geri dönüş, sevilmek istediği gibi başka insanları seven insanlarda olduğu gibi kendilik ve nesne işlevlerinin yer değiştirmesi ve klinik psikiyatride en zorlayıcı sendromlardan biri olan narsistik kişilik bozukluğu olmak üzere üç şekilde ele alınmaktadır. Patolojik kendini sevme, kendini merkeze alma ve sürekli kendinden bahsetmeyle kendini göstermektedir. Bu durum büyüklenme gösterileri, teşhircilik eğilimi, üstünlük hissi, düşüncesizlik ve aşırı hırslı olma gibi özellikleri barındırmaktadır. Ayrıca narsistik eğilimi olan kişiler başkalarının kendine hayran olması konusunda aşırı bağımlılık gösterilebilmektedir (Kernberg, 2004).

Freud narsisizm kavramını normal bir gelişim aşaması, benlik saygısının normal bir yönü, kişiler arası ilişkilerde özellikle eş seçiminde kişinin kendine benzer özellikleri tercih etmesi ve kişilerarası ilişkilerden yoksun olma gibi çok farklı şekillerde kullanmıştır (Levy ve diğerleri, 2011). Narsisizm çok boyutlu yapısıyla ilişkili olarak çelişkili süreçler ve sonuçlarla ilişkili görünmektedir. Narsistlerin karizması ve kendine güveni onlara başkalarını büyüleyen muazzam bir enerji verebilirken saldırgan davranışları ve empati eksikliği onları insanlardan uzaklaştırabilmektedir (Back ve arkadaşları, 2013). Narsisizmin her zaman patolojik 
olmadığını, normal narsisizm ya da patolojik olmayan narsisizm özelliklerinin benlik saygısıyla ilişkili olabileceği ifade edilmektedir (Miller ve Campbell, 2011). Narsisizm ve benlik saygısı arasındaki ilişkiyi inceleyen çalışmalarda narsisizm ve benlik saygısı çoğunlukla pozitif ilişkili bulunmaktadır (Bosson ve diğerleri, 2008; Bosson ve Weaver, 2011; Sedikides, Rudich, Gregg, Kumashiro ve Rusbult, 2004). Bazı araştırmacılar, narsisizmi tek boyutlu bir yapı olarak ele alırken diğerleri ise narsisizmin iki boyutu arasında ayrım yapmaktadır (Miller, Gentile ve Campbell, 2013, Sherman ve arkadaşları, 2015, Wink, 1991). Bu iki bileşenli yaklaşımların en yaygın olanı, büyüklenmeci (açı) ve kırılgan (örtük) narsisizm arasındaki ayrımı içermektedir (Bosson ve Weaver, 2011).

Büyüklenmeci narsisizm büyüklenme, kibir, saldırganlık, baskınlık, teşhircilik, dışadönüklük ve yüksek öz güven özelliklerini içerirken, kırılgan narsisizm içe dönüklük, düşmanlık yetersizlik hissi, düşük benlik saygısı özelliklerini yansıtmaktadır (Miller ve diğerleri, 2011; Wink, 1991). Büyüklenmeci narsisizm dışadönüklük ve yetkinlik ile pozitif ilişkiliyken yumuşak başlılık ve nevrotizm kişilik özelliğiyle negatif ilişkilidir. Büyüklenmeci narisizm benlik bilinci, kırılganlık, depresyon ve kaygı ile negatif ilişki göstermektedir. Kırılgan narsisizm ise nevrotiklik ile pozitif ilişkiliyken yumuşak başlılık, dışa dönüklük ve sorumluluk kişilik özellikleriyle ve olumlu duygularla negatif ilişkilidir. Ayrıca kırılgan narsisizm benlik bilinci öfke ve düşmanlık hassasiyet, depresyon, kaygı ve dürtüsellik ile pozitif ilişkilidir (Miller ve Maples, 2011). Bu araştırmada kullanılan narsisizm kavramı kırılgan narsisizmi, bir patolojik durumu ya da kişilik bozukluğunu değil genel popülasyonda bir kişilik özelliği olarak büyüklenmeci narsisizmi işaret etmektedir. Narsistik hayranlık ve rekabet büyüklenmeci narsisizmin iki farklı boyutu olarak değerlendirilmektedir.

Narsisizm, benliğin aşırı derecede şişirilmesini ve benlikle ilgili gerçekçi olmayan olumlu görüşleri, kendine odaklanmayı, haklılık hissini, kişilerarası ilişkilere ve bağlara önem vermemeyi ve empati eksikliğini yansıtan kendine özgü düşünme, hissetme ve davranma sitillerini içermektedir (Campbell ve Foster, 2007).

Narsisizmi iyi ya da kötü olarak nitelendirmek yerine narsisizmin farklı bileşenlerine, sosyal bağlama ve sonuçlarına odaklanmak faydalı görünmektedir. Sosyal ilişkileri başlatmak ve lider olmak gibi sosyal bağlamlarda ve kişinin kendi ve yetenekleri hakkında olumlu görüşe sahip olmak gibi sonuç değişkenlerinde narsisizmin bazı yararları bulunmaktadır. Öte yandan ilişkiler sürdürülme ve uzun vadeli karar verme gibi sosyal bağlamlarda ve doğru öz-bilgi gibi sonuç değişkenlerinde narsisizmin bazı zararların bulunmaktadır (Campbell ve Foster, 2007). Büyüklenmeci narsisizm hem olumlu benlik algısı, liderlik ve kısa dönemli ilişkilerde kişilerarası başarı olumlu sonuçlar hem de ilişki problemleri, saldırganlık ve aldatma gibi olumsuz sonuçlarla ilişkili bulunmuştur (Campbell ve Campbell, 2009). Narsisizm şaşırtıcı bir yapıdır çünkü görünüşte birbiriyle ilgisiz veya hatta zıt olan öz-düzenleme süreçleri, özellikleri ve kişilerarası sonuçları ile ilgilidir (Back ve diğerleri, 2013). Narsisizmin yararları yani eylemli yönü daha kısa dönemli ilişkilerde ve ilişkilerin erken evrelerinde görülürken zararları yani 
düşmanca yönü daha çok uzun vadeli ilişkilerde ve durumlarda görülmektedir (Back ve diğerleri, 2013; Campbell ve Campbell, 2009). Başka bir araştırmada atılgan davranışların popüler olmayı olumlu etkilediği, düşmanca davranışların ise popülerliği olumsuz etkilediği bulunmuştur (Küfner, Nestler ve Back, 2013). Bu gibi sonuçlar narsisizmin farklı dinamikleri olan süreçlerle ilişkili olduğunu göstermektedir.

Kendini geliştirme ve kendini koruma, kişilik ve sosyal psikolojinin genel ilkeleri olarak kabul edilmektedir. İnsanlar olumlu benlik algısını artırmak için (kendini geliştirme) ve olumsuz benlik algısına karşı kendilerini savunmak için (kendine koruma) motive olmaktadırlar. İnsanın zevk peşinde olması ve acında kaçmasının ifade eden hedonik ilke motivasyon teorileri açısından kendini geliştirme ve kendini koruma yönleriyle ele alınmaktadır (Alicke ve Sedikides, 2009, 2011; Higgins, 1998; Back ve diğerleri, 2013). Hem kendini geliştirme hem de kendimi koruma olumlu benlik algısının oluşturmayı ve sürdürmeyi hedeflemektedir. Bu temel motivasyonlar büyüklenmeci narsisizm açısından ele alındığında temel hedef görkemli benliğin oluşturulması ve sürdürülmesi olmaktadır (Back ve diğerleri, 2013).

Araştırmalar narsisizmin alt boyutlarının farklı̈̈zellikliler göstermesi nedeniyle toplam puan yerine alt boyutlarının ayrı ayrı değerlendirilmesinin daha faydalı olabileceğini göstermektedir. $\mathrm{Bu}$ araştırmada kullanılan narsistik hayranlık ve rekabet modeline göre narsisizm birbiriyle pozitif ilişkili ancak birbirinden iki farklı boyuttan oluşmaktadır. Narsistler temel hedefi olan yüceltilmiş benliği korumak için iki farklı sosyal strateji kullanmaktadır. Bunlardan biri sosyal hayranlığı sağlamak için kendilerini tanıtmaktır. Diğeri ise sosyal başarısızlığı önlemek için kendilerini savunmaktır. Bu iki strateji birebirinden farklı duygusal-motivasyonel, bilişsel ve davranışsal yollar izlemektedir. Ancak bu iki strateji de temel hedef olan yüceltilmiş benliği sürdürmeye katkı sağladığı için birbiriyle pozitif ilişkilidir (Back ve diğerleri, 2013).

Narsisistik Hayranlık ve Rekabet Kavramı, narsisizmin kendini geliştirme yoluyla yönlendirilen eylemli yönü olan hayranlık ve kendini savunma tarafından yönlendirilen düşmanca yönü olan rekabet boyutlarıyla büyüklenmeci narsisizmin öz-düzenleme süreçlerini açıklamaktadır (Leckelt ve arkadaşları, 2016). Narsistik Hayranlık ve Rekabet Kavramı Şekil l'de açıklanmaktadır (Back ve diğerleri, 2013, s. 1015).

Narsistik hayranlık olarak adlandırılan atılgan kendini geliştirme süreci birbiriyle ilişkili üç narsistik eğilimden oluşmaktadır. Bunlar benzersizlik çabası (duygusal-motivasyonel), büyüklenme fantezileri(bilişsel) ve cazibe (davranışsal) eğilimleridir. Bu süreçler sosyal statü, başarı, övgü, lider olarak seçilme, sosyal kaynaklar elde etme, çekicilik ve sosyal ilgi uyandırma gibi olumlu sosyal sonuçlar ortaya çıkarmaktadır. Narsistik rekabet olarak adlandırılan düşmanca kendini koruma süreci de birbiriyle ilişkili üç narsistik eğilimden oluşmaktadır. Bunlar üstünlük çabası (duygusal-motivasyonel), başkalarını değersizleştirme (bilişsel) ve saldırganlık (davranışsal) eğilimleridir. Bu süreçler reddedilme, ilişkilerde sınırların ihlal edilmesi, popüler olmama, eleştiri ve güvenilmezlik gibi olumsuz sosyal sonuçlar ortaya çıkarmaktadır (Back ve diğerleri, 2013). 


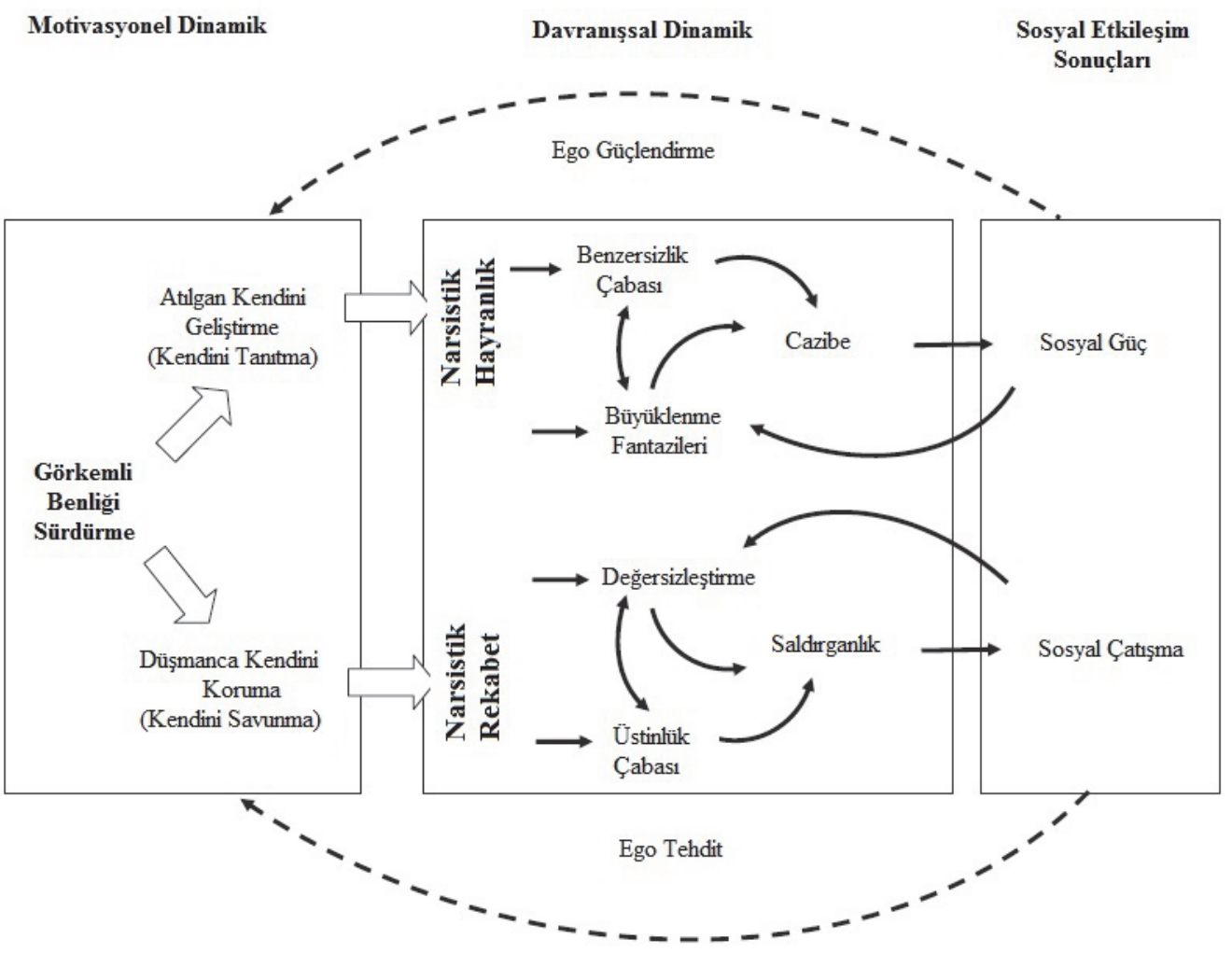

Şekil I. Narsistik Hayranlık ve Rekabet Kavramı (Back ve diğerleri, 2013, s. 1015).

Narsistik hayranlık ve rekabet öz-düzenleme stratejileri görkemli benliğe hizmet ederken birbirinden oldukça farklı sosyal sonuçlar doğurmaktadır. Bu bağlamda hayranlık narsisizmin aydınlık yönü olarak ele alınırken, rekabet narsisizmin karanlık yönü olarak ele alınmaktadır (Back ve diğerleri, 2013). Büyüklenmeci narsisizmin hayranlık ve rekabet boyutlarıyla temel belirleyicilerinden birinin insan ilişkileri olan mutluluk kavramı arasındaki ilişkilerin incelenmesi bu iki boyutlu kavramsallaştırmanın kişisel ve kişilerarası sonuçlarının anlaşılmasına katkı sağlayabilir.

Antik çağlardan beri mutluluk birçok filozof, yazar ve din adamı tarafından en yüksek iyi olarak kabul edilmektedir (Begum, Jabeen ve Awan, 2014; Cevizci, 2002). Modern dünyada bir çok düşünür, psikoloji alanında çalışmalar yapan bir çok araştırmacı mutluluğun istenilirliği ve faydaları üzerinde durmaktadır. Çeşitli disiplinlerin bakış açıları mutluluğun ne olduğu konusunda farklı açıklamalar getirmiştir. Günümüzde mutluluğun en çok kabul gören tanımlarından biri kökeni hazcı felsefeye dayanan öznel iyi oluş kuramıdır. Hazcı bakış açısı hoşa giden deneyimleri arttırmayı, acı veren deneyimleri azaltmayı gerektiren ve haz alınan anların toplamı olarak gören bir yaklaşımdır (Ryan ve Deci, 2001). 
Öznel iyi oluş yaklaşıma göre mutluluk, kişinin olumlu duyguların olumsuz duygulardan daha çok yaşanması ve yaşamından doyum almasıdır (Diener, 1984). Bu bakış açısına göre mutluluk genel olarak öznel deneyimlerle ilişkilidir. Lyubomirsky ve Lepper (1999) mutlulukla ilgili farklı anlayışların olmasına rağmen insanlar ister zengin olduklarında, ister gerçek aşkı bulduklarında, ister işlerinde başarılı olduklarında ister manevi huzura ulaştıklarında mutlu olsunlar bir şekilde mutlu olduklarının farkında olduklarını ifade etmektedir. Öte yandan bazı insanlar olumsuz yaşam koşullarına rağmen mutlu olabilirken, bazıları iyi durumda olmalarına rağmen mutsuz olabilmektedir (Lyubomirsky ve Lepper, 1999; Myers ve Diener, 1995). Bu durum mutluluğun daha çok öznel deneyimlerle ilişkili olduğunu göstermektedir. Öznel Mutluluk Ölçeği kişinin kendisinin mutlu hissedip hissetmemesini ve akranlarına göre ne derece mutlu olduğunu ölçen iki madde ve mutluluk ve mutsuzluk tanımlamalarının verilerek kişiye ne derece uyduğunu ölçen iki madde olmak üzere 4 maddeden oluşmaktadır. İnsanlar kendi mutlulukları ya da mutlulukları konusunda görüş bildirebilmektedir (Lyubomirsky ve Lepper, 1999).

Narsisizmin çok boyutlu doğası çeşitli araştırmalardan patolojik narsisizm ve patolojik olmayan narsisizm, büyüklenmeci narsisizm ve kırılgan narsisizm, açık narsisizm ve örtük narsisizm şeklinde ele alınmıştır. Örtük narsisizm, patolojik narsisizm ve kırılgan narsisizm genel olarak psikopatoloji ile pozitif ilişkiliyken, patolojik olmayan narsisizm, açık narsisizm ve büyüklenmeci narsisizm iyi oluşla pozitif ilişkili bulunmaktadır. Narsisizmle mutluluk arasındaki ilişkiyi inceleyen bir çalışmada açık narsisizm mutlulukla pozitif ilişkili, örtük narsisizm ile mutlulukla negatif ilişkili bulunmuştur. Açı narsisizm ve örtük narsisizm ile mutluluk arasındaki ilişkiye öz-saygı aracılık etmektedir. Açık narsistler öz-saygıları yüksek olduğu için daha mutlu olmaktayken, örtük narsistler öz güveni düşük olduğu için mutsuz olmaktadır (Rose, 2002). Narsisizm ve benlik saygısı arasındaki ilişkiyi inceleyen çalışmalarda narsisizm ve benlik saygısı çoğunlukla pozitif ilişkili bulunmaktadır. Narsisizm ve iyi oluş arasındaki ilişkiye öz-saygının tam aracılık ettiği ifade edilmektedir (Sedikides, Rudich, Gregg, Kumashiro ve Rusbult, 2004). Öte yandan boylamsal çalışmalarda narsisizmin iyi oluş ileriye dönük belirleyicisi olmadığı bulunmuştur. Narsisizm öz-saygının ileriye dönük bir belirleyicisiyken öz-saygının narsisizmin ileriye dönük belirleyicisi olmadığı ifade edilmiştir. (Zuckerman ve O’Loughlin, 2009).

Daha önceki çalışmalardaki büyüklenmeci ve açık narsisizm açıklamalarından farklı olarak hayranlık ve rekabet modeli narsisizmin temel amacı olan yüceltilmiş benliği sürdürmek için atılgan kendini geliştirme ya da düşmanca benliği koruma stratejilerini kullanıldı̆̆ını vurgulamaktadır. Bu anlamda narsistik hayranlığın benlik saygısı ve kişilerarası ilişkilerle bağlantılı olarak mutluluk ile pozitif ilişkili olması beklenmektedir. Narsistik rekabetin ise kişiler arası çatışmalar nedeniyle mutluluk ile negatif ilişkili olması beklenmektedir. Bu araştırmanın temel amacı büyüklenmeci narsisizmin aydınlık ve karanlık yönlerini ifade eden hayranlık ve rekabetin mutlulukla ilişkisinin incelenmesidir. Bu araştırmanın bir diğer amacı Narsistik Hayranlık ve Rekabet Ölçeği’nin uzun ve kısa formalarını Türkçeye uyarlamak ve psikometrik özelliklerini incelemektir. 


\section{Yöntem}

Narsistik Hayranlık ve Rekabet ile mutluluk kavramları arasındaki ilişkilerin belirlenmesi için yapısal eşitlik modeli kullanılmıştır. İlk aşamada Narsistik Hayranlık ve Rekabet Ölçeğỉnin yapı geçerliği doğrulayıcı faktör analizi, güvenirliği iç tutarlık yöntemiyle incelenmiştir. Ölçekteki maddeler düzeltilmiş madde-toplam puan korelasyonu ile analiz edilmiştir. Ardından Narsistik Hayranlık ve Rekabet ile mutluluk arasındaki ilişki için yapısal eşitlik modeli kullanılmıştır. Yapısal eşitlik modeli için AMOS 20, doğrulayıcı faktör analizi için LISREL 8.88, madde analizi, iç tutarlık analizleri ve korelasyon analizleri için SPSS 20.0 programları kullanılmıştır.

Yapısal eşitlik modelinde ve doğrulayıcı faktör analizinde test edilen modelin uyum iyiliğini belirlemek için Kline (2015) önerisine uygun olarak Ki-Kare Uyum Testi, CFI, NFI, NNFI, SRMR RMSEA uyum iyiliği indeksleri kullanılmıştır. Daha önceki çalışmalarda kabul edilebilir uyum değerleri RMSEA ve SRMR için .08 (Brown ve Cudeck, 1993; Byrne ve Campbell, 1999), CFI, NFI ve NNFI için .90 (Bentler, 1980; Bentler ve Bonett, 1980; Schermelleh-Engel ve Moosbrugger, 2003) olduğu ifade edilmiştir. Ki-Kare Uyum Testi için ise $x^{2} /$ sd değerinin ise 3'ün altında (Schermelleh-Engel ve Moosbrugger, 2003) olması kabul edilebilir uyumun göstergesidir.

\section{Çalışma Grubu}

Araştırmanın örneklemi Marmara Üniversitesinin çeşitli bölümlerinde öğrenim gören 336’s1 (\%80) kadın ve 80’i erkek (\%20) olmak üzeri toplam 420 öğrenciden oluşmaktadır. Katılımcıların 4'ü cinsiyetini belirtmemiştir. Katılımcıların çoğunluğu eğitim fakültesinde öğrenim görmektedir. Marmara Üniversitesi Eğitim fakültesinde kadın öğrencilerin oranı (\%62) erkek öğrencilere (\%38) göre yüksek olduğu için kadın ve erkek katılımcıların oranları arasında bu kadar fark olduğu düşünülmektedir. Katılımcıların yaşları 21 ile 24 arasında değişmektedir ve yaş ortalamaları 23,04 ( \pm 1,02) olarak hesaplanmıştır. Uyum geçerliği için Ölçek ile Narsistik Kişilik Envanteri arasındaki ilişkiler 50 öğrenciden toplanan veriler üzerinde incelenmiştir. Narsisizm ve mutluluk arasındaki ilişkiler 279 kadın ve 59 erkek olmak üzeri 338 öğrenciden oluşan çalışma grubu üzerinde incelenmiştir. Katılımcıların 3'ü cinsiyetini belirtmemiştir. Katılımcıların yaşları 21 ile 24 arasında değişmektedir ve yaş ortalamaları 23,10 ( $\pm 1,01)$ olarak bulunmuştur.

\section{Veri Toplama Araçları}

Narsistik Hayranlık ve Rekabet Ölçeği: Back ve arkadaşları (2013) tarafından geliştirilen Narsistik Hayranlık ve Rekabet Ölçeği büyüklenmeci narsisizmi birbiriyle ilişkili olan hayranlık (eylemlilik) ve rekabet (düşmanlık) boyutlarıyla ölçmektedir. Ölçeğin 18 madde ve 6 madde olmak üzere iki formu bulunmaktadır. Ölçek 6'lı Likert tipi derecelendirmeye göre puanlanmaktadır. Ölçeğin hayranlık boyutu büyüklenme, benzersizlik ve cazibe alt boyutlarından oluşmaktadır. Rekabet boyutu ise saldırganlık, üstünlük, değersizleştirme boyutlarında oluşmaktadır. Ölçeğin 18 maddeli ve 6 maddelik 2 boyutlu yapısının doğrulayıcı faktör analizi sonucunda yeterli uyum verdiği görülmüştür. 18 maddelik formda iç tutarlık katsayıları toplam puan için .80 hayranlık 
üst boyutu için .84 ve rekabet üst boyutu için .80 olarak bulunmuştur. Hayranlık ve rekabet üst boyutlarının alt boyutları için ise iç tutarlık katsayısı .62 ile .79 arasında değişmiştir. Kısa formun iç tutarlık katsayısı toplam puan için .74, hayranlık alt boyutu için .76 ve rekabet boyutu için .61 olarak bulunmuştur (Back ve arkadaşları, 2013). Bir diğer çalışmada kısa formun geçerlik ve güvenirlik özelliklerinin kabul edilebilir düzeyde olduğu görülmüştür. Kolay örneklemde kısa formun iç tutarlık katsayısı hayranlık için .74 ve rekabet için .61 olarak bulunmuştur. Temsili örneklemde ise iç tutarlık katsayısı hayranlık için .84 ve rekabet için .70 olarak bulunmuştur (Leckelt ve arkadaşları, 2016). Bu araştırmada uzun formun hayranlık üst boyutu toplam varyansın $\% 41,845$ 'ini açılklarken rekabet üst boyutu toplam varyansın \%42,903'ünü açıklamaktadır. Kısa formun hayranlık üst boyutu toplam varyansın \%56,665'ini açılarken rekabet üst boyutu toplam varyansın \%67,035'ini açıllamaktadır.

Öznel Mutluluk Ölçeği: Lyubomirsky ve Lepper (1999) tarafından geliştirilen, Dogan ve Totan, (2013) tarafından Türkçeye uyarlanan, 4 maddeden oluşan, tek boyutlu bir yapıya sahip olan ölçek, 7'li Likert tipi bir derecelendirmeye göre puanlanmaktadır. Ölçeğin psikometrik özellikleri açımlayıcı ve doğrulayıcı faktör analizi, iç tutarlık ve ölçüt bağıntılı geçerlik yöntemleriyle incelenmiştir. Ölçeğin Cronbach alfa iç tutarlılık güvenirlik katsayısı üniversite grubunda .70, halk grubundan .65 olarak bulunmuştur. ÖMÖ, Oxford Mutluluk Ölçeği, Yaşam Doyumu Ölçeği, Yaşam Yönelimi Ölçeği ile pozitif ilişkili bulunmuştur. Bu araştırmada Öznel Mutluluk Ölçeği toplam varyansın \%42,903'ünü açıklamaktadır.

Narsistik Kişilik Envanteri: Ames, Rose ve Anderson, (2006) tarafından geliştirilen, 16 maddeden oluşan ölçek 2'li derecelendirmeye göre puanlanmaktadır. Atay (2009) tarafından Türkçeye uyarlanan Ölçeğin iç tutarlılığı .63 olarak hesaplanmıştır. Türkçe formun açımlayıcı faktör analizi sonrasında orijinal formda olduğu gibi teşhircilik, üstünlük, otorite, hak iddia etme, sömürücülük, kendine yeterlilik alt boyutlarından oluştuğu ve bu faktörlerin toplam varyansın $\% 60,8$ 'ini açıkladı̆̆ bulunmuştur.

\section{Bulgular}

Çalışma 1.1: Narsistik Hayranlık ve Rekabet Ölçeği'nin Psikometrik Özellikleri

\section{Çeviri Süreci}

Narsistik Hayranlık ve Rekabet Ölçeğinnin Türkçeye uyarlama çalışması için ölçeği geliştirenlerden Mitja Back ile e-mail yoluyla iletişime geçilmiş ve ölçeğin Türkçeye uyarlanması için izin alınmıştır. Ölçek önce iyi derecede İngilizce bilen beş akademisyen tarafından bağımsız olarak Türkçeye çevrilmiştir. Daha sonra ilk çeviri grubundan iki kişi ve narsisizm alanında çalışmalar yapmış bir uzman ile çeviriler arasındaki uyumu kontrol ederek ortak bir çeviri oluşturmuşlardır. İngilizce ve Türkçe formun uyumlu olduğu tespit edildikten sonra bir Türkçe öğretmeni ile Türkçe formdaki maddeler üzerinde değerlendirmeler yaparak Türkçe forma son hali verilmiştir. 


\section{Yapı Geçerliği}

Ölçeğin orijinal formundaki faktör yapısını değerlendirmek üzere doğrulayıcı faktör analizi yapılmıştır. Orijinal formdaki 18 maddeli, 2 üst boyutlu ve 6 alt boyutlu ölçme modelinin Türkçe formdaki uyum indeksi değerlerinin kabul edilebilir düzeyde olduğu görülmüştür $\left(\chi_{(128, N=420)}^{2}\right.$ $=302,43, p<.001 ; \mathrm{CFI}=.96 ; \mathrm{NFI}=.94 ; \mathrm{NNFI}=.96$; $\mathrm{SRMR}=.052 ; \mathrm{RMSEA}=.057(.049-.065)$. Ölçeğin altı boyutlu faktör yapısı ve faktörler arasındaki ilişkileri Şekil 2'de görülmektedir. Ölçeğin faktör yükleri .39 ile .86 arasında değişmektedir. Modelin uyum indeksleri incelendiğinde ölçeğin altı boyutlu modelinin kabul edilebilir düzeyde uyum verdiği görülmüştür.

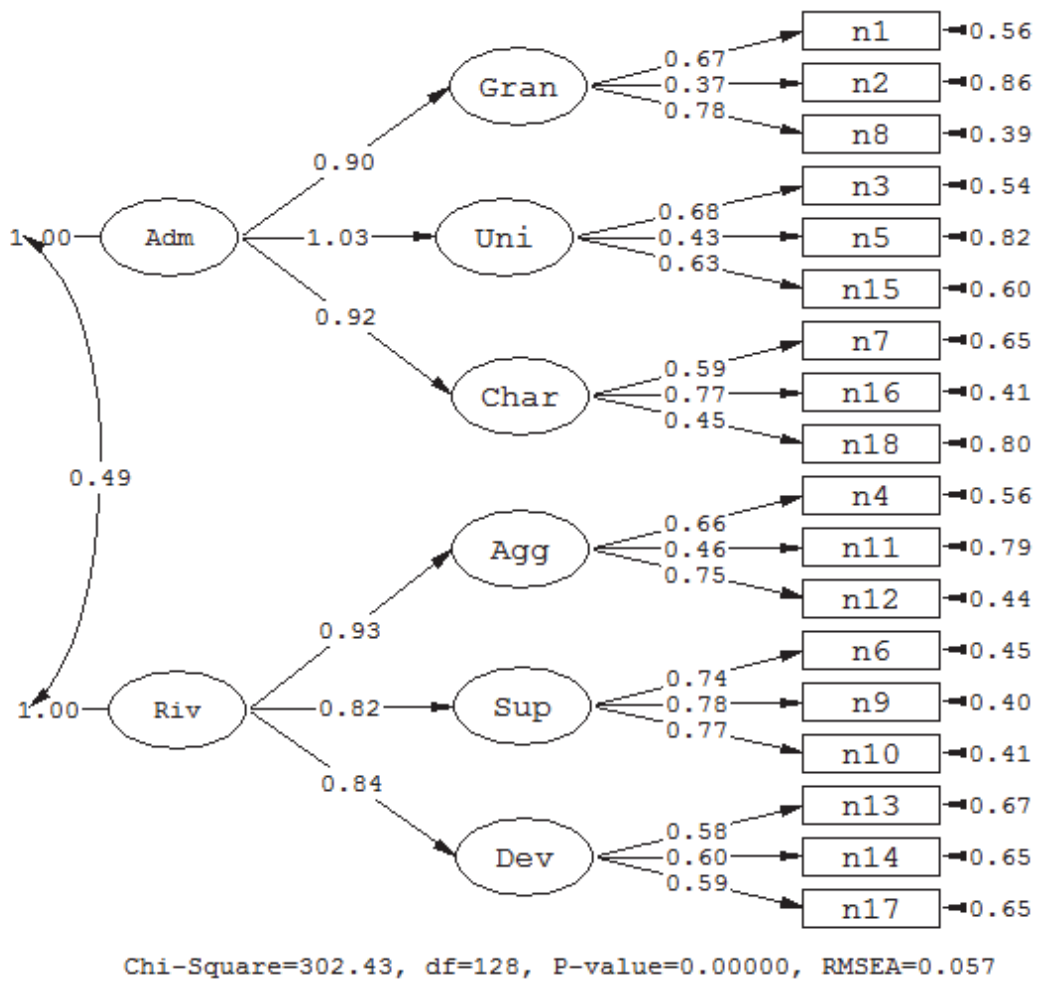

Şekil 2. Narsistik Hayranlık ve Rekabet Ölçeği’nin Yol Diyagramı ve Faktör Yükleri

\section{Madde Analizi ve Güvenirlik}

Narsistik Hayranlık ve Rekabet Ölçeği’nin madde analizi düzeltilmiş madde toplam puan korelasyonlarını inceleyerek yapılmıştır. Ölçeğin madde toplam puan korelasyonları büyüklenme alt boyutu için .30 ile .55 , benzersizlik alt boyutu için .38 ile .48, cazibe alt boyutu için .41 ile .49, saldırganlık alt boyutu için .34 ile .58, üstünlük alt boyutu için .63 ile .64, değersizleştirme alt boyutu için .36 ile .48, arasında değişmektedir. Bulgular Tablo 1'de verilmiştir. 


\section{Tablo I.}

Narsistik Hayranlık ve Rekabet Ölçeği'nin Madde Analizleri ve Betimsel İstatistikler

\begin{tabular}{|c|c|c|c|c|c|c|c|c|c|c|c|}
\hline \multirow[b]{2}{*}{ Üst Boyutlar } & \multirow[b]{2}{*}{$\overline{\mathrm{x}}$} & \multirow[b]{2}{*}{ Ss } & \multirow[b]{2}{*}{ Alt Boyutlar } & \multirow[b]{2}{*}{$\overline{\mathrm{x}}$} & \multirow[b]{2}{*}{ Ss } & \multirow[b]{2}{*}{ M. No } & \multicolumn{5}{|c|}{ Madde Toplam Puan Korelasyonları } \\
\hline & & & & & & & $\overline{\mathrm{x}}$ & Ss & $\mathbf{r}_{\mathrm{mdt}}$ & $\mathbf{r}_{\text {mdü }}$ & $\mathbf{r}_{\text {mda }}$ \\
\hline \multirow{9}{*}{ Hayranlık } & \multirow{9}{*}{3.50} & \multirow{9}{*}{0.89} & \multirow{3}{*}{ Büyüklenme } & \multirow{3}{*}{3.16} & \multirow{3}{*}{1.05} & $\mathrm{~m} 1$ & 3.97 & 1.25 & 0.47 & 0.58 & 0.55 \\
\hline & & & & & & $\mathrm{m} 2$ & 2.16 & 1.40 & 0.35 & 0.34 & 0.30 \\
\hline & & & & & & $\mathrm{m} 8$ & 3.34 & 1.43 & 0.58 & 0.64 & 0.45 \\
\hline & & & \multirow{3}{*}{ Benzersizlik } & \multirow{3}{*}{3.80} & \multirow{3}{*}{1.27} & $\mathrm{~m} 3$ & 2.91 & 1.40 & 0.59 & 0.60 & 0.41 \\
\hline & & & & & & m5 & 4.79 & 1.33 & 0.32 & 0.40 & 0.38 \\
\hline & & & & & & $\mathrm{m} 15$ & 3.69 & 1.61 & 0.52 & 0.54 & 0.48 \\
\hline & & & \multirow{3}{*}{ Cazibe } & \multirow{3}{*}{3.54} & \multirow{3}{*}{1.18} & $\mathrm{~m} 7$ & 3.85 & 1.35 & 0.44 & 0.54 & 0.45 \\
\hline & & & & & & $\mathrm{m} 16$ & 2.94 & 1.38 & 0.57 & 0.64 & 0.49 \\
\hline & & & & & & $\mathrm{m} 18$ & 3.84 & 1.34 & 0.27 & 0.40 & 0.41 \\
\hline \multirow{9}{*}{ Rekabet } & \multirow{9}{*}{2.13} & \multirow{9}{*}{0.81} & \multirow{3}{*}{ Saldırganlık } & \multirow{3}{*}{2.68} & \multirow{3}{*}{0.89} & $\mathrm{~m} 4$ & 2.82 & 1.42 & 0.48 & 0.52 & 0.41 \\
\hline & & & & & & $\mathrm{m} 11$ & 3.06 & 1.32 & 0.33 & 0.40 & 0.34 \\
\hline & & & & & & $\mathrm{m} 12$ & 2.16 & 1.22 & 0.51 & 0.61 & 0.58 \\
\hline & & & \multirow{3}{*}{ Üstünlük } & \multirow{3}{*}{1.99} & \multirow{3}{*}{0.66} & $\mathrm{~m} 6$ & 2.18 & 1.36 & 0.47 & 0.56 & 0.63 \\
\hline & & & & & & $\mathrm{m} 9$ & 2.08 & 1.30 & 0.53 & 0.62 & 0.63 \\
\hline & & & & & & $\mathrm{m} 10$ & 1.72 & 1.12 & 0.54 & 0.68 & 0.64 \\
\hline & & & \multirow{3}{*}{ Değersizleştirme } & \multirow{3}{*}{1.71} & \multirow{3}{*}{0.57} & $\mathrm{~m} 13$ & 1.94 & 1.26 & 0.38 & 0.46 & 0.41 \\
\hline & & & & & & $\mathrm{m} 14$ & 1.31 & 0.87 & 0.41 & 0.49 & 0.48 \\
\hline & & & & & & $\mathrm{m} 17$ & 1.89 & 1.29 & 0.39 & 0.48 & 0.36 \\
\hline
\end{tabular}

Ölçeğin toplam puanının iç tutarlılık katsayısı .85 olarak hesaplanmıştır. Üst boyutların iç tutarlık katsayısı Hayranlık için .83 ve Rekabet için .82 olarak bulunmuştur. Alt boyutların iç tutarlık katsayısı büyüklenme için .62, benzersizlik için .61, cazibe için .64, saldırganlık için .63, üstünlük için .79, değersizleştirme için .60, olarak hesaplanmıştır.

Katılımcıların hayranlık puanlarının cinsiyet değişkenine göre anlamlı bir farklılık gösterip göstermediğini belirlemek üzere yapılan $t$ testi sonucunda erkek $(\mathrm{N}=80, \overline{\mathrm{x}}=3.66 \pm 0.89)$ ve kadın $(\mathrm{N}=336, \overline{\mathrm{x}}=3.46 \pm 0.89)$ katılımcılar arasında anlamlı bir fark bulunmamıştır $(t=1.78, p>.05, d$ $=0.22$ ). Katılımcıların rekabet puanlarının cinsiyet değişkenine göre anlamlı bir farklılık gösterip göstermediğini belirlemek üzere yapılan $t$ testi sonucunda erkek katılımcıların $(\mathrm{N}=80, \overline{\mathrm{x}}=2.32$ $\pm 0.90)$ kadın katılımcılardan $(\mathrm{N}=336, \overline{\mathrm{x}}=2,08 \pm 0,78)$ anlamlı bir şekilde yüksek puan aldı $\breve{g} 1$ görülmüştür $(t=2.35, p<.05, d=0.29)$. 
Çalışma 1.2: Kısa Narsistik Hayranlık ve Rekabet Ölçeği’nin Psikometrik Özellikleri

\section{Yapı Geçerliği}

Ölçeğin orijinal formundaki faktör yapısını değerlendirmek üzere doğrulayıcı faktör analizi yapılmıştır. Orijinal formdaki 6 maddeli, 2 alt boyutlu ölçme modelinin Türkçe formdaki uyum indeksi değerlerinin kabul edilebilir düzeyde olduğu görülmüştür $\left(\chi_{(8, \mathrm{~N}=420)}^{2}=6,95, p>.05\right.$; CFI = $1.00 ; \mathrm{NFI}=.99 ; \mathrm{NNFI}=1.00 ;$ SRMR $=.018 ;$ RMSEA $=.00(.00-.052)$. Ölçeğin iki boyutlu faktör yapısı ve faktörler arasındaki ilişkileri Şekil 3’de görülmektedir. Ölçeğin faktör yükleri .54 ile .74 arasında değişmektedir. Modelin uyum indeksleri incelendiğinde ölçeğin iki boyutlu modelinin kabul edilebilir düzeyde uyum verdiği görülmüştür.

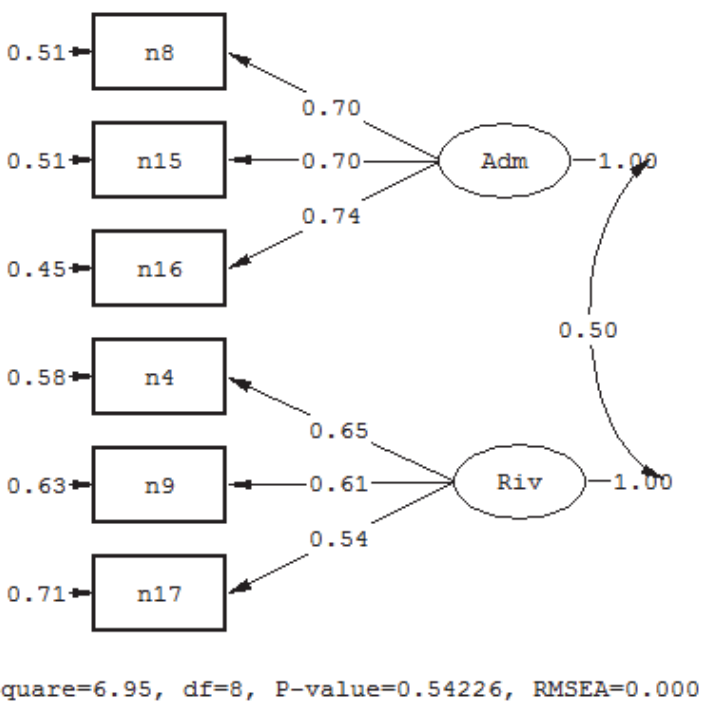

Şekil 3. Kısa Narsistik Hayranlık ve Rekabet Ölçeği’nin Yol Diyagramı ve Faktör Yükleri

\section{Madde Analizi ve Güvenirlik}

Kısa Narsistik Hayranlık ve Rekabet Ölçeği’nin madde analizi düzeltilmiş madde toplam puan korelasyonlarını inceleyerek yapılmıştır. Ölçeğin madde toplam puan korelasyonları Hayranlık alt boyutu için .57 ile .61, Rekabet alt boyutu için .39 ile .45, arasında değişmektedir. Bulgular Tablo 2'de verilmiştir. 
Tablo 2.

Kısa Narsistik Hayranlık ve Rekabet Ölçeği'nin Madde Analizleri

\begin{tabular}{lccccccc}
\hline \multirow{2}{*}{ Alt Boyutlar } & & \multicolumn{5}{c}{ Madde Toplam Puan Korelasyonlari } \\
& \multirow{2}{*}{ Hayranlik } & Ss & M. No & $\overline{\mathrm{x}}$ & Ss & $\mathbf{r}_{\text {mdt }}$ & $\mathbf{r}_{\text {mda }}$ \\
\hline \multirow{3}{*}{ Rekabet } & \multirow{2}{*}{3.32} & \multirow{2}{*}{1.20} & $\mathrm{~m} 8$ & 3.34 & 1.43 & 0.41 & 0.57 \\
& & & $\mathrm{~m} 15$ & 3.69 & 1.61 & 0.42 & 0.57 \\
& \multirow{2}{*}{2.27} & \multirow{2}{*}{1.01} & $\mathrm{~m} 16$ & 2.94 & 1.38 & 0.35 & 0.61 \\
\hline
\end{tabular}

$\mathbf{r}_{\text {mdt }}$ Toplam puan için madde toplam puan korelasyonu

$\mathbf{r}_{\text {mda }}$ Alt boyut için madde toplam puna korelasyonu

Ölçeğin toplam puanının iç tutarlılık katsayısı .72 olarak hesaplanmıştır. İç tutarlık katsayısı Hayranlık alt boyutu için .75 ve Rekabet alt boyutu için .62 olarak bulunmuştur.

Çalışma 1.3: Uyum Geçerliği ve Narsistik Hayranlık ve Rekabet Ölçeğỉnin alt boyutları ile uzun ve kısa formları arasındaki ilişkiler

Ölçeğin uyum geçerliği için 50 kişilik bir çalışma grubuna Narsistik Hayranlık ve Rekabet Ölçeği ve Narsistik Kişilik Envanteri (NPI-16) birlikte uygulanmış ve puanlar arasındaki korelasyonlar incelenmiştir. Ayrıca 420 katılımcının yer aldığ verilerle Narsistik Hayranlık ve Rekabet Ölçeğinin uzun form ve kısa form arasındaki ve alt boyutları arasındaki korelasyon katsayıları incelenmiştir. Bulgular Tablo 3’te yer almıştır.

Tabloda bulunan bütün korelasyon katsayıları $(p<.05)$ anlamlı bulunmuştur. Uzun formun toplam puanı ve kısa formun toplam puanı arasındaki korelasyon katsayısı .92 $(p<.01)$, hayranlık alt boyunun uzun formu ve kisa formu arasındaki korelasyon katsayıs1 .87 $(p<.01)$, rekabet alt boyunun uzun formu ve kisa formu arasindaki korelasyon katsayısı $.88(p<.01)$, olarak bulunmuştur. Ölçeğin alt boyutları arasındaki korelasyon katsayıları .18 $(p<.01)$ ile .58 $(p<.01)$, arasında değişmektedir. 
Tablo 3.

Kısa Narsistik Hayranlık ve Rekabet Ölçeği'nin Alt boyutları ile Narsistik Kişilik Envanteri arasındaki korelasyon katsayıları

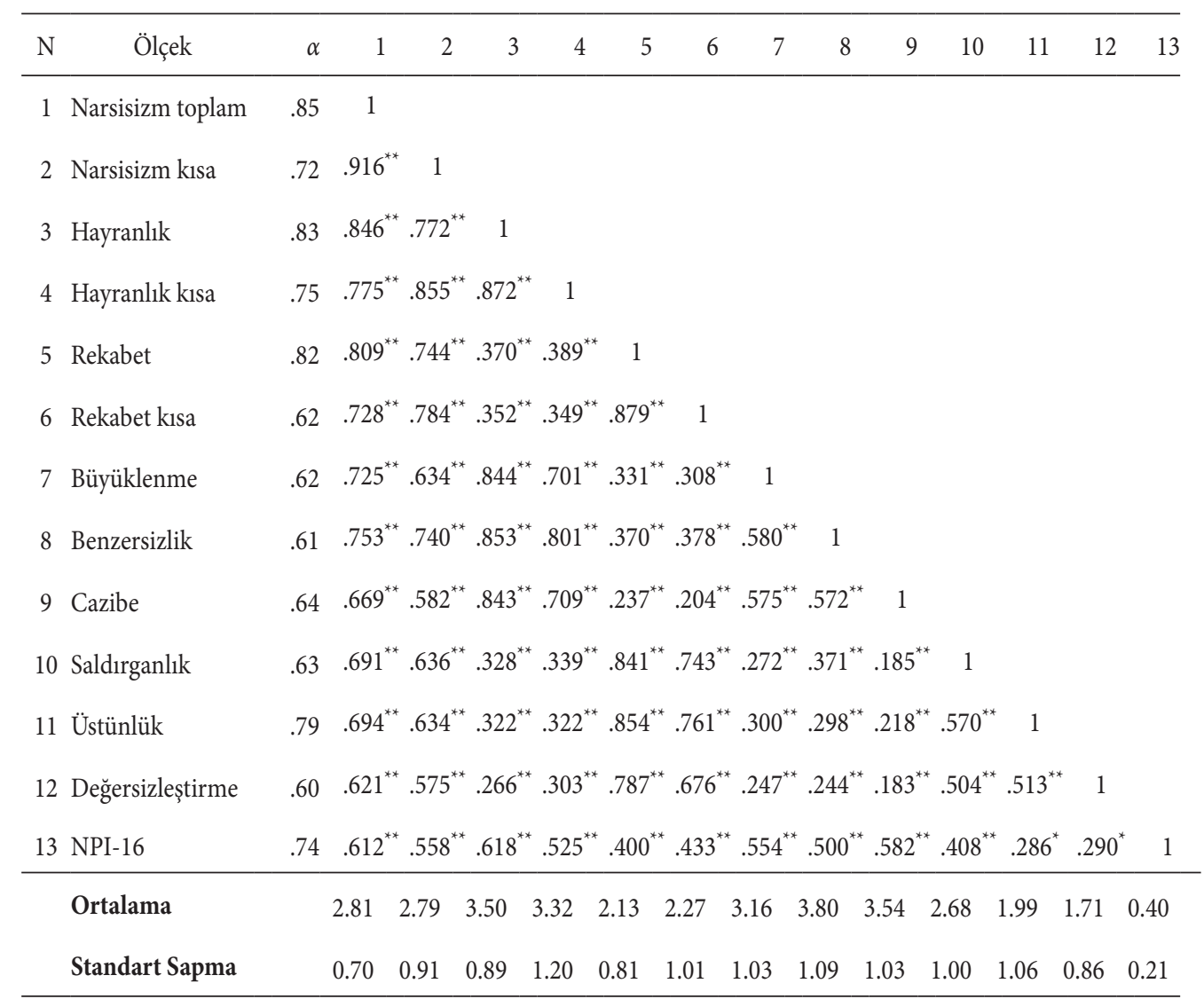

${ }^{*} p<.05 .{ }^{* *} p<.01 .1-12$ arasındaki değişkenler için $N=420 . N P I-16$ için $N=50$

Narsistik Kişilik Envanteri’nin değişkenler arasındaki korelasyon katsayıları; ölçeğin uzun formunun toplam puanı ile $.62(p<.01)$, kısa formun toplam puanı ile $.56(p<.01)$, hayranlık alt boyutunun uzun formu ile $.62(p<.01)$, kisa formu ile $.53(p<.01)$, rekabet alt boyunun uzun formu ile $.40(p<.01)$, kisa formu ile .43 ( $p<.01)$, alt boyutlardan büyüklenme ile $.55(p<.01)$, benzersizlik ile $.50(p<.01)$, cazibe ile $.58(p<.01)$, saldırganlık için .41 $(p<.01)$, üstünlük için .29 $(p<.05)$, değersizleştirme için .29 ( $p<.05)$, olarak hesaplanmıştır.

Çalışma 2: Narsistik Hayranlık ve Rekabet ile Mutluluk Arasındaki İlişki

Yapısal eşitlik modeli için değişkenler arasında çoklu doğrusal bağıntı olup olmadığı değerlendirilmiştir. Analiz öncesinde Varyans Büyütme Faktörü (VIF) değerlerinin 10’un altında ve korelasyon değerlerinin .85 'in altında olduğu görülmüştür. Analiz öncesinde çarpıklık 
(skewness) ve basıklık (kurtosis) değerleri hesaplanarak değişkenlerin normal dağılıma sahip olup olmadığı incelenmiştir. Değişkenlerin çarpıklık ve basıklık değerlerinin -2 ve +2 arasında olduğu görülmüştür. Hayranlık alt boyutunun iç tutarlık katsayısı .80, Rekabet alt boyutunun iç tutarlık katsayısı .78, Öznel Mutluluk Ölçeği'nin iç tutarlık katsayısı .62 olarak bulunmuştur. Yapısal eşitlik modelinin belirlenmesi için öncelikle değişkenler arasındaki ilişkiye bakılmıştır. Ölçekler ve alt boyutlar arasındaki korelasyon katsayılarını ve betimsel istatistiklerini gösteren bulgular Tablo 4'de yer almaktadır. Değişkenlerin çarpıklık değerlerinin -.184 ile -1.289 arasında, basıklık değerlerinin ise -.162 ile 1,769 arasında değiştiği görülmektedir.

\section{Tablo 4.}

Değişkenler arasındaki korelasyon katsayıları ve betimsel istatistikler

\begin{tabular}{llccccccccc}
\hline $\mathrm{N}$ & Ölçek & 1 & 2 & 3 & 4 & 5 & 6 & 7 & 8 & 9 \\
\hline 1 & Hayranlık & 1 & & & & & & & & \\
2 & Rekabet & $.314^{* *}$ & 1 & & & & & & & \\
3 & Büyüklenme & $.829^{* *}$ & $.266^{* *}$ & 1 & & & & & & \\
4 & Benzersizlik & $.842^{* *}$ & $.360^{* *}$ & $.542^{* *}$ & 1 & & & & & \\
5 & Cazibe & $.827^{* *}$ & $.150^{* *}$ & $.539^{* *}$ & $.540^{* *}$ & 1 & & & & \\
6 & Saldırganlık & $.281^{* *}$ & $.845^{* *}$ & $.219^{* *}$ & $.361^{* *}$ & $.111^{*}$ & 1 & & & \\
7 & Üstünlük & $.281^{* *}$ & $.826^{* *}$ & $.252^{* *}$ & $.282^{* *}$ & $.164^{* *}$ & $.528^{* *}$ & 1 & & \\
8 & Değersizleştirme & $.170^{* *}$ & $.705^{* *}$ & $.150^{* *}$ & $.198^{* *}$ & .071 & $.442^{* *}$ & $.374^{* *}$ & 1 & \\
9 & Mutluluk & $.156^{* *}$ & $-.169^{* *}$ & $.145^{* *}$ & .053 & $.198^{* *}$ & $-.126^{*}$ & -.092 & $-.208^{* *}$ & 1 \\
\hline & Ortalama & 3.47 & 2.04 & 3.11 & 3.77 & 3.53 & 2.60 & 1.91 & 1.63 & 17.88 \\
& Standart Sapma & 0.85 & 0.71 & 1.00 & 1.08 & 1.00 & 0.98 & 0.99 & 0.71 & 4.03 \\
& Çarpıklık & -.142 & .920 & .136 & -.184 & -.081 & .592 & 1.280 & 1.289 & -.153 \\
& Basılılı & -.075 & .744 & -.162 & -.517 & -.345 & .138 & 1.769 & 1.354 & .477 \\
\hline
\end{tabular}

Değişkenler arasındaki korelasyonlar incelendikten sonra narsistik hayranlık ve rekabet ile mutluluk arasındaki ilişki yapısal eşitlik modeli ile test edilmiştir. Narsistik hayranlık ve rekabet ile mutluluk ilişkilerine yönelik yapısal eşitlik modelinin uyum iyiliği indekslerinin kabul edilebilir düzeyde olduğu görülmektedir; $\chi_{(32, \mathrm{~N}=338)}^{2}=57,8, p<.001 ; \mathrm{CFI}=.97$; NFI = .93; NNFI = .95; SRMR = .046; RMSEA = .049 (.028 - .069). Kurulan yapısal eşitlik narsistik hayranlık dişsal gizil değişkeninin mutluluğu $(\beta=.34, t=4.24, p<.01)$ pozitif yönde yordadı̆̆ , narsistik rekabet dışsal gizil değişkeninin ise mutluluğu $(\beta=-.33, t=-4.16, p<.01)$ negatif yönde yordadığı bulunmuştur. Yapısal eşitlik modeli Şekil 4'de görülmektedir. 


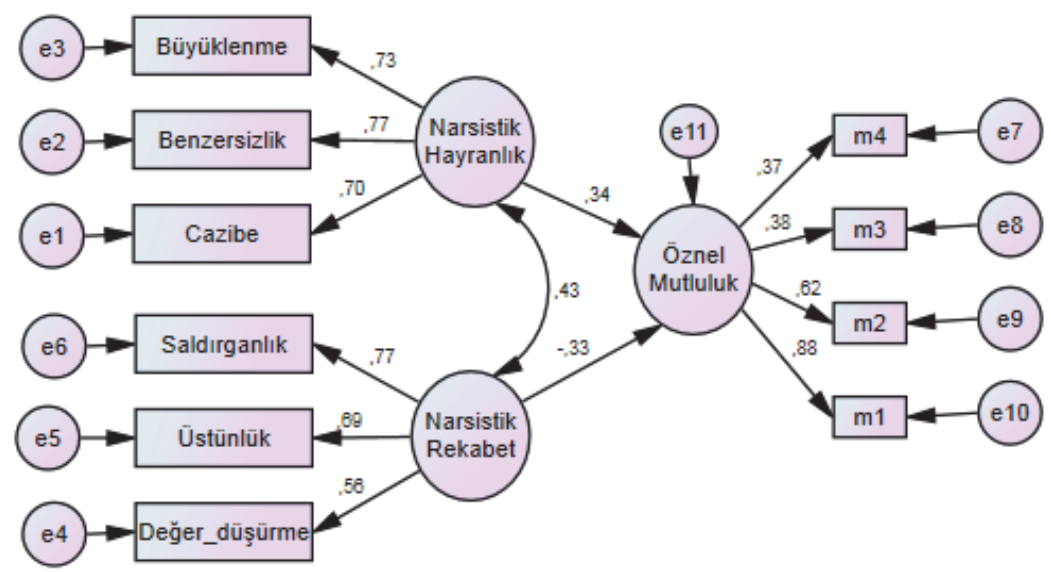

Şekil 4. Narsistik Hayranlık ve Rekabet İle Mutluluk İlişkilerine Yönelik Yapısal Eşitlik Modeli

\section{Tartışma}

Bu çalışmada Narsistik Hayranlık ve Rekabet Ölçeği'nin uzun ve kısa formunun Türkçeye uyarlanması ve narsistik hayranlık ve rekabet ile mutluluk arasındaki ilişkilerin incelenmesi amaçlanmıştır. Ölçek iyi derecede İngilizce bilen beş akademisyen tarafından bağımsız olarak Türkçeye çevrilmiştir. Ardından narsisizm alanında çalışmalar yapmış üç uzman çevirileri değerlendirerek ortak bir çeviri oluşturmuştur. Son düzenlemelerin yapılarak Türkçe form uygulamaya hazır hale getirilmiştir.

Doğrulayıcı faktör analizi sonuçlarına göre, Narsistik Hayranlık ve Rekabet Ölçeği’nin uzun ve kısa formunun uyum indeksi değerlerinin kabul edilebilir düzeyde olduğu tespit edilmiştir. Ölçeğin uzun ve kısa formunun büyüklenmeci narsisizmin hayranlık ve rekabet boyutlarını ölçmek için kullanılabileceğini göstermektedir. Ölçeğin uzun formu ve kısa formu arasındaki yüksek ilişkiler iki ölçeğin de kullanımının uygun olduğunu göstermektedir.

Ölçeğin güvenirlik özelliklerini incelemek için Cronbach alpha iç tutarlılık katsayısı hesaplanmıştır. Cronbach alpha iç tutarlık katsayısının .70’in üzerinde olmasının kabul edilebilir olduğu ifade edilmektedir (Kline, 2000). Ölçekteki uzun formun hayranlık ve rekabet boyutlarının güvenirliğinin kabul edilebilir düzeyde olduğu görülmüştür. Alt boyutların iç tutarlık katsayıları ise üstünlük için kabul edilebilir düzeyde olduğu, büyüklenme, benzersizlik, cazibe, saldırganlık, değersizleştirme boyutları için .60 ile .64 arasında olduğu bulunmuştur. Ölçeğin araştırmalarda kullanımının hayranlık ve rekabet boyutları üzerinden olmasının daha uygun olduğu görülmektedir. Kısa formun hayranlık alt boyutunun iç tutarlığı kabul edilebilir düzeydeyken, rekabet boyutunun iç tutarlığı .62 olarak bulunmuştur. Bu sonuçlar 
orijinal kısa formun rekabet boyutunun iç tutarlık katsayılarıyla benzerlik göstermektedir (Back ve arkadaşları, 2013; Leckelt ve arkadaşları, 2016). Alt boyutlardaki güvenirlik katsayıları .70’in altında olmasına karşın Aiken ve Groth-Marnat (2006) bireysel değerlendirme amacı gütmeyen çalışmalarda güvenirlik katsayısının .60 düzeyinde olmasının yeterli olduğunu öne sürmektedir. Uzun form ve kısa form arasındaki korelasyon katsayıları kısa formun da araştırmalarda kullanılabileceğinin bir göstergesi olarak kabul edilebilir. Ancak 18 maddelik formun kullanılmasıyla narsisizm gibi karmaşık bir yapının daha uygun bir şekilde incelenebileceği söylenebilir.

Narsistik Hayranlık ve Rekabet Ölçeği ile Narsistik Kişilik Envanteri arasındaki pozitif ilişkiler uyum geçerliğinin göstergesi olarak kabul edilebilir. Ancak bu ilişkinin örneklem sayısının düşük olması bir sınırlılık olarak ifade edilebilir. Bununla birlikte küçük bir örneklemde bu ilişkilerin bulunması daha büyük örneklem gruplarındaki ilişkinin daha anlamlı olacağının göstergesidir.

Ölçeğin madde analizi, düzeltilmiş madde toplam korelasyonları incelenerek yapılmıştır. Ölçekteki maddelerin toplam puan, üst boyut puanı ve alt boyut puanı arasındaki korelasyonların .30 üzerinde olduğu bulunmuştur. Düzeltilmiş madde toplam korelasyonlarının .30 ve üzerinde olmasının her bir maddenin benzer bir davranışı örneklediğinin göstergesi olduğu ifade edilmektedir (Büyüköztürk, 2010).

Narsistik hayranlık ve rekabet ile mutluluk arasındaki ilişki yapısal eşitlik modeli ile incelenmiştir. Narsistik hayranlığın ve rekabetin mutluluğu yordadığı modelin uyum iyiliği indekslerinin kabul edilebilir düzeyde olduğu bulunmuştur. Narsistik hayranlık mutluluğu pozitif yönde yordarken, narsistik rekabet mutluluğu negatif yönde yordamaktadır. Narsistik hayranlık ve rekabetin mutluluğu yordama gücünün neredeyse eşit olduğu görülmüştür.

Araştırmalar narsisizmin alt boyutlarının farklı özellikler göstermesi nedeniyle toplam puan yerine alt boyutlarının ayrı ayrı değerlendirilmesinin daha faydalı olabileceğini göstermektedir. $\mathrm{Bu}$ araştırmada kullanılan narsistik hayranlık ve rekabet modeline göre narsisizm birbiriyle pozitif ilişkili ancak birbirinden iki farklı boyuttan oluşmaktadır. Narsisizm düzeyi yüksek olan kişilerin temel hedefi yüceltmiş oldukları benliklerini korumaktır. Yüceltilmiş benliği korumak için iki farklı sosyal strateji kullanmaktadır. Bunlardan biri sosyal hayranlığı sağlamak ve kendini çevresine tanıtarak kişinin kendi reklamını yapmasıdır. Diğeri ise sosyal başarısızlı̆̆ önlemek için kişinin kendini savunmasıdır. Bu iki strateji birbirinden farklı duygusalmotivasyonel, bilişsel ve davranışsal yollar izlemektedir. Ancak bu iki strateji de temel hedef olan yüceltilmiş benliği sürdürmeye katkı sağladığ 1 için birbiriyle pozitif ilişkilidir Ancak aynı amaca farklı yollarla hizmet etmeleri nedeniyle diğer değişkenlerle farklı ilişkiler içinde olabilmektedir (Back ve diğerleri, 2013).

Hayranlık ve rekabetin mutlulukla farklı ilişkiler içinde olması bu iki boyutun farklı dinamikleri ile açıklanabilir. Hayranlık boyutunun dinamiği duygusal-motivasyonel açıdan 
benzersiz olma çabası, bilişsel açıdan büyüklenme fantezileriyle ve davranışsal açıdan narsistik cazibe ile açıklanmaktadır. Bu durum kişinin başarılı olmasına ve sosyal statü kazanmasını gibi sosyal potansiyel sağlayabilmektedir. Rekabet boyutunun dinamiği ise duygusal-motivasyonel açıdan üstünlük çabası, bilişsel açıdan diğerlerini küçük görmeyle ve ortaya çıkan davranışsal açıdan saldırganlık ile açıklanmaktadır. Bu durum ise kişinin popüler olmamasına ve dışlanması gibi kişilerarası çatı̧̧malara yol açabilmektedir (Back ve diğerleri, 2013). Mutluluğun en önemli içsel belirleyicilerinden biri olan öz-saygı ve dişsal belirleyicilerinden olan sosyal ilişkiler olduğu söylenebilir. Hayranlığın öz-saygı ve olumlu sosyal ilişkilerle ilişkilendirilebilecek yapısı mutluluğu pozitif yordamasının açıklayıcısı olabilir. Öte yandan rekabetin düşük ya da gerçek dışı öz-saygı ve olumsuz sosyal ilişkilerle ilişkilendirilebilecek yapısı mutluluğu negatif yordamasının açılayıcısı olabilir.

Daha önceki çalı̧̧malarda narsistik hayranlık duygusal dengesizlik ile negatif ilişkiliyken dışa dönüklük, deneyime açıllık ve öz-saygı ile pozitif ilişkili bulunmuştur. Narsistik rekabet ise dışa dönüklük, yumuşak başlılık, sorumluluk, öz-saygı, empati, affedicilik, minnettarlık ile negatif ilişkiliyken, duygusal dengesizlik, intikam, kişilerarası güvensizlik, dürtüsellik ve öfke ile pozitif ilişkili bulunmuştur (Back ve arkadaşları, 2013; Leckelt ve arkadaşları, 2016). Narsisizmin mutlulukla ilişkisinin incelendiği çalışmalarda açık narsisizmin öz-saygı aracılığıyla mutluluğu pozitif yönde yordadığı, örtük narsisizm öz-saygı aracıllğıyla mutluluğu negatif yönde yordadığ 1 bulunmuştur (Rose, 2002). Türkiye'de yürütülen bir çalışmada benzer olarak kırılgan narsisizmin psikopatolojik belirtiler ile pozitif, yaşam doyumu ile negatif ilişkili ve büyüklenmeci narsisizm ise yaşam doyumu ile pozitif ilişkili bulunmuştur (Akıncı, 2015).

$\mathrm{Bu}$ araştırmada elde edilen bulgular Narsistik Hayranlık ve Rekabet Ölçeği’nin uzun ve kısa formlarının Türkiyede yürütülecek bilimsel çalışmalarda kullanılabileceğini göstermektedir. Daha sonraki çalışmalarda benlik saygısı ve kişilik özellikleri ile ilişkilerin incelenmesiyle, davranışsal bazı değerlendirmelerin yapılmasıyla ve zaman içindeki değişmezliğin belirlenmesi için test tekrar test güvenirlik çalışmanın yapılmasıyla ölçeğin psikometrik özellikleri hakkında daha ayrıntılı bilgiler elde edilebilir. Ölçeğin boyutlarının kendi içinde pozitif ilişkiliyken, çeşitli kavramlarla birbirine zıt ilişki içinde olmasının kuramsal ve uygulamalı araştırmalar için önemli bir avantaj olacağı düşünülmektedir.

$\mathrm{Bu}$ araştırmada ulaşılan narsistik hayranlığın mutlulukla olumsuz ilişkili olduğu ve narsistik rekabetin mutlulukla olumsuz ilişkili olduğu bulgusu narsisizm karanlık ve aydınlık doğasının anlaşılmasına katkı sağlamaktadır. Ayrıca narsistik hayranlık ve rekabetin mutluluk üzerindeki zıt etkileri öz-saygı ve sosyal ilişkiler bağlamında mutluluğun doğasının anlaşılması açısından faydalı olabilir. Kişinin kendisine hayran olarak benliğini yüceltmesi ve olumlu sosyal sonuçlara ulaşması mutlu olmasına katkı sağlarken, kişinin çevresini rakip olarak benliğini koruma çabasıyla çevresiyle çatışma içinde olması mutlu olmasını engelleyebilmektedir. 
Narsistik Hayranlık ve Rekabet Ölçeği

\begin{tabular}{|c|c|c|c|c|c|c|c|}
\hline \multicolumn{2}{|r|}{$\begin{array}{l}\text { Aşağıdaki ifadelerin her birine ne derece katıldığınızı, yanındaki kutucuklarda } \\
\text { yer alan " } 1=\text { Hiç katılmıyorum" ile " } 6=\text { Tamamen Katılıyorum” } \\
\text { arasındaki rakamlardan yalnızca birinin üstüne }(X) \text { işareti koyarak gösteriniz. }\end{array}$} & 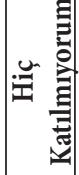 & & & & & 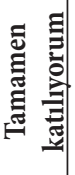 \\
\hline 1 & Harika biriyim. & 1 & 2 & 3 & 4 & 5 & 6 \\
\hline 2 & Günün birinde ünlü olacağım. & 1 & 2 & 3 & 4 & 5 & 6 \\
\hline 3 & Ne kadar özel biri olduğumu diğerlerine gösteririm. & 1 & 2 & 3 & 4 & 5 & 6 \\
\hline $4 \mathrm{k}$ & Başka biri beni gölgede bırakırsa sinirlerim. & 1 & 2 & 3 & 4 & 5 & 6 \\
\hline 5 & Başarılarımdan fazlasıyla keyif alırım. & 1 & 2 & 3 & 4 & 5 & 6 \\
\hline 6 & Rakiplerimin başarısızlığından gizli bir zevk alırım. & 1 & 2 & 3 & 4 & 5 & 6 \\
\hline 7 & Sohbet ederken çoğu zaman insanların ilgisini üzerime çekebilirim. & 1 & 2 & 3 & 4 & 5 & 6 \\
\hline $8 \mathrm{k}$ & Harika bir kişilik olarak görülmeyi hak ediyorum. & 1 & 2 & 3 & 4 & 5 & 6 \\
\hline $9 \mathrm{k}$ & Rakiplerimin başarısız olmasını isterim. & 1 & 2 & 3 & 4 & 5 & 6 \\
\hline 10 & Başka insanların benden aşağı bir konumda olmaları hoşuma gider. & 1 & 2 & 3 & 4 & 5 & 6 \\
\hline 11 & Eleștirildiğimde sıklıkla rahatsız olurum. & 1 & 2 & 3 & 4 & 5 & 6 \\
\hline 12 & Bir başkasının ilgi odağı olmasına hiç tahammül edemem. & 1 & 2 & 3 & 4 & 5 & 6 \\
\hline 13 & Çoğu insan hiç bir şey başaramaz. & 1 & 2 & 3 & 4 & 5 & 6 \\
\hline 14 & Diğer insanların hiç bir değeri yoktur. & 1 & 2 & 3 & 4 & 5 & 6 \\
\hline $15 \mathrm{k}$ & Çok özel bir insan olmak bana çok büyük bir güç verir. & 1 & 2 & 3 & 4 & 5 & 6 \\
\hline $16 \mathrm{k}$ & Yaptığım olağanüstü işlerle ilgi odağı olmayı başarıyorum. & 1 & 2 & 3 & 4 & 5 & 6 \\
\hline $17 \mathrm{k}$ & Çoğu insan öyle ya da böyle eziktir. & 1 & 2 & 3 & 4 & 5 & 6 \\
\hline 18 & Çoğunlukla diğer insanları idare etme konusunda oldukça ustayımdır. & 1 & 2 & 3 & 4 & 5 & 6 \\
\hline
\end{tabular}

$\mathrm{k}=$ Kisa formda bulunan maddeler 


\section{Kaynakça}

Aiken, L. \& Groth-Marnat, G. (2006). Psychological testing and assessment (12th ed.). Boston: Allyn and Bacon.

Akınc1, İ. (2015). The relationship between the types of narcissism and psychological well-being: The roles of emotions and difficulties in emotion regulation. Middle East Technical University, The Department of Psychology,(Master's Thesis), Ankara.

Alicke, M. D., \& Sedikides, C. (2009). Self-enhancement and self-protection: What they are and what they do. European Review of Social Psychology, 20, 1-48.

Amerikan Psikiyatri Birliği. (2013). DSM-5 tanı ölçütleri başvuru el kitabı (Çev., E.,Köroğlu). Ankara, Hekimler Yayın Birliği.

Ames, D. R., Rose, P., \& Anderson, P. C. (2006), The NPI-16 as a short measure of narcissism. Journal of Research in Personality, 40, 440-450.

Atay, S. (2009). Narsistik Kişilik Envanteri’nin Türkçeye standardizasyonu. Gazi Üniversitesi İktisadi ve İdari Bilimler Fakültesi Dergisi, 11(1), 181-196.

Back, M. D., Küfner, A. C., Dufner, M., Gerlach, T. M., Rauthmann, J. F., \& Denissen, J. J. (2013). Narcissistic admiration and rivalry: Disentangling the bright and dark sides of narcissism. Journal of Personality and Social Psychology, 105(6), 1013.

Begum, S., Jabeen, S., \& Awan, A. B. (2014). Happiness: A psycho-philosophical appraisal. Dialogue, 9(3), 314.

Bentler, P. M. (1980). Multivariate analysis with latent variables: Causal modeling. Annual Review of Psychology, 31, 419-456.

Bentler, P. M., \& Bonet, D. G. (1980). Signifcance tests and goodness of fit in the analysis of covariance structures. Psychological Bulletin, 88, 588-606.

Brown, M., \& Cudeck, R. (1993). Alternative ways of assessing model fit. In: K. A. Bollen ve J. S. Long (Eds.), Testing structural equation models (s. 136-162). Beverly Hills, CA: Sage.

Büyüköztürk, Ş. (2011). Sosyal bilimler için veri analizi el kitabı: İstatistik, araştırma deseni SPSS uygulamaları ve yorum. Ankara: PEGEM A Yayıncilik.

Byrne, B. M., \& Campbell, T., L. (1999). Cross-cultural comparisons and the presumption of equivalent measurement and theoretical structure: a look beneath the surface. Journal of Cross-Cultural Psychology, 30, 555-574.

Campbell, K. W. \& Foster, J., D. (2007). The narcissistic self: Background, an extended agency model, and ongoing controversies. In C. Sedikides, \& S. Spencer (Eds.), The self (p. 115-138). New York: Psychology Press.

Campbell, W. K., \& Campbell, S. M. (2009). On the self-regulatory dynamics created by the peculiar benefits and costs of narcissism: A contextual reinforcement model and examination of leadership. Self and Identity, 8, 214-232.

Cevizci, A. (2010). Felsefe tarihi. Say yayınları: İstanbul.

Davenport, S. W., Bergman, S. M., Bergman, J. Z., \& Fearrington, M. E. (2014). Twitter versus Facebook: Exploring the role of narcissism in the motives and usage of different social media platforms. Computers in Human Behavior, 32, 212-220.

Diener, E. (1984). Subjective well-being. Psychological Bulletin, 95, 542-575.

Dogan, T., \& Totan, T. (2013). Psychometric properties of Turkish version of the Subjective Happiness Scale. The Journal of Happiness \& Well-Being, 1(1), 21-28.

Ellis, H. (1898). Auto- eroticism: A psychological study. Alienist and Neurologist, 19, 260-299. 
Freud, S. (1957). On narcissism: An introduction. In J. Strachey (Ed. and Trans.), The standard edition of the complete psychological works of Sigmund Freud (Vol. 14, pp. 73-102). London, England: Hogarth Press. (Orijinal bask1 1914) https://manhattanpsychoanalysis.com/wp- content/uploads/readings/ Hartmans_course\%20Upload/10._Freud_on_narcissism.pdf adresinden edinilmiştir.

Gentile, B., Miller, J. D., Hoffman, B. J., Reidy, D. E., Zeichner, A., \& Campbell, W. K. (2013). A test of two brief measures of grandiose narcissism: The Narcissistic Personality Inventory-13 and the Narcissistic Personality Inventory-16. Psychological assessment, 25(4), 1120.

Grijalva, E., Harms, P. D., Newman, D. A., Gaddis, B. H., \& Fraley, R. C. (2015). Narcissism and leadership: A meta-analytic review of linear and nonlinear relationships. Personnel Psychology, 68(1), 1-47.

Higgins, E. T. (1998). Promotion and prevention: Regulatory focus as a motivational principle. In M. P. Zanna (Ed.), Advances in experimental social psychology (Vol. 30, pp. 1-46). New York, NY: Academic Press.

Horney, K. (1939). New ways in psychoanalysis. New York, NY: Horton. http://www.verlaine.pro.br/txt/ horney-new-ways.pdf adresinden edinilmiştir.

Kernberg, O. (2004). Aggressivity, narcissism, and self-destructiveness in the psychotherapeutic relationship: New developments in the psychopathology and psychotherapy of severe personality disorders. Yale University Press.

Kline, P. (2000). Handbook of psychological testing. London: Routledge.

Kline, R. B. (2015). Principles and practice of structural equation modeling. New York: Guilford publications.

Kohut, H. (1977). Restoration of the self. New York: International University Press.

Küfner, A. C. P., Nestler, S., \& Back, M. D. (2013). The two pathways to being an (un-)popular narcissist. Journal of Personality, 81, 184-195.

Leckelt, M., Wetzel, E., Gerlach, T. M., Ackerman, R. A., Miller, J. D., Chopik, W. J., ... \& Richter, D. (2016). Validation of the Narcissistic Admiration and Rivalry Questionnaire short scale (NARQ-S) in convenience and representative samples. Psychological Assessment, doi: 10.1037/pas0000433.

Levy, K. N., Ellison, W. D., \& Reynoso, J. S. (2011). A historical review of narcissism and narcissistic personality. In W. K. Campbell \& J. D. Miller (Eds.), The Handbook of Narcissism and Narcissistic Personality Disorder, Theoretical Approaches, Empirical Findings, and Treatments (pp. 3-13). Hoboken, NJ: John Wiley \& Sons, Inc.

Lyubomirsky, S., \& Lepper, H. S. (1999). A measure of subjective happiness: Preliminary reliability and construct validation. Social Indicators Research, 46, 37-155.

Miller, J. D., \& Campbell, W. K. (2011). Addressing criticisms of the narcissistic personality inventory (NPI). In W. K. Campbell \& J. D. Miller (Eds.), The handbook of narcissism and narcissistic personality disorder, theoretical approaches, empirical findings, and treatments (pp. 146-152). Hoboken, NJ: John Wiley \& Sons, Inc.

Miller, J. D., Gentile, B., \& Campbell, W. K. (2013). A test of the construct validity of the Five-Factor Narcissism Inventory. Journal of Personality Assessment, 95, 377-387.

Myers, D. G., \& Diener, E. (1995). 'Who is happy?. Psychological Science, 6, 10-19.

Näcke, P. (1899). Die sexuellen perversitäten in der irrenanstalt. Psychiatriche en Neurologische Bladen, 3, $122-149$.

Rose, P. (2002). The happy and unhappy faces of narcissism. Personality and individual differences, 33(3), 379-391.

Rousseau, B. M., \& Duchon, D. (2015). Organizational narcissism: Scale development and firm outcomes. Journal of Organizational Culture, Communications and Conflict, 19(1), 159-175. 
Ryan, R. M., \& Deci, E. L. (2001). On happiness and human potentials: A review of research on hedonic and eudaimonic well-being. In S. Fiske (Eds.), Annual Review of Psychology, 52, 141-166). Palo Alto, CA: Annual Reviews, Inc.

Schermelleh-Engel, K., \& Moosbrugger, H. (2003). Evaluating the fit of structural equation models: Tests of significance and descriptive goodness-of-fit measures. Methods of Psychological Research Online, $8(2), 23-74$.

Sedikides, C., Rudich, E. A., Gregg, A. P., Kumashiro, M., \& Rusbult, C. (2004). Are normal narcissists psychologically healthy?: Self-Esteem matters. Journal of Personality and Social Psychology, 87, 400-416.

Sherman, E. D., Miller, J. D., Few, L. R., Campbell, W. K., Widiger, T. A., Crego, C., \& Lynam, D. R. (2015). Development of a short form of the Five-Factor Narcissism Inventory: The FFNISF. Psychological Assessment, 27(3), 1110-1116.

Wurst, S. N., Gerlach, T. M., Dufner, M., Rauthmann, J. F., Grosz, M. P., Küfner, A. P., \& ... Back, M. D. (2017). Narcissism and romantic relationships: The differential impact of narcissistic admiration and rivalry. Journal of Personality and Social Psychology, 112(2), 280-306. 